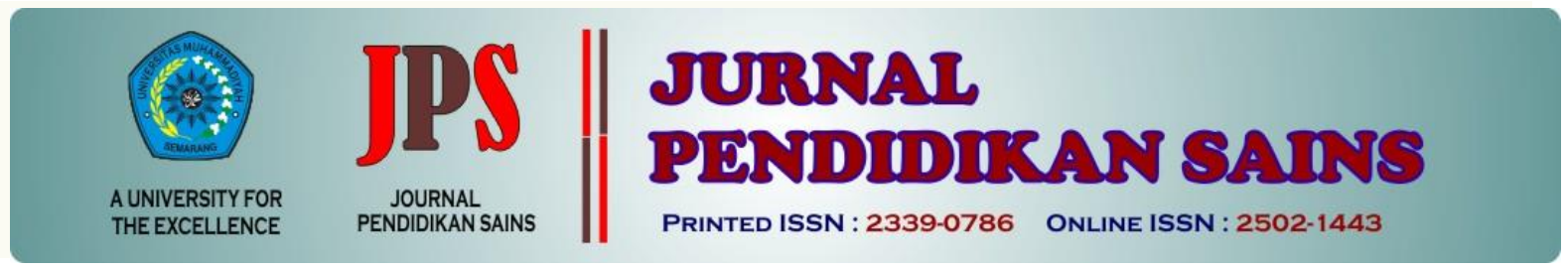

http://jurnal.unimus.ac.id/index.php/JPKIMIA

\title{
PENGARUH METODE DISCOVERY-INQUIRY TERHADAP PROFIL KETERAMPILAN BERPIKIR KRITIS SISWA PADA PEMBELAJARAN TOPIK KELARUTAN
}

Oleh:

Fina Khaerunnisa Frima ${ }^{1,2}$, Gun Gun Gumilar ${ }^{1}$, FM Titin Supriyanti ${ }^{1}$

${ }^{1}$ Universitas Pendidikan Indonesia Bandung

${ }^{2}$ Insitut Teknologi Sumatera Lampung Selatan

\begin{tabular}{|c|c|c|}
\hline Article hist & & Abstract \\
\hline Submission & : 2020-01-12 & \multirow{5}{*}{$\begin{array}{l}\text { The era of industrial revolution } 4.0 \text { contributes major challenges in } 21^{\mathrm{s}} \\
\text { century of education in obtaining qualified students. Education process } \\
\text { lead to the development of student skills and attitudes in addition to } \\
\text { the knowledge learning process. Critical thinking skills (KBKr) is one } \\
\text { of the } 21^{\text {st }} \text { century learning skills that students should have and needs } \\
\text { to be practiced during learning process in school. One of the learning } \\
\text { method to practice KBKr is discovery-inquiry learning method. The } \\
\text { purpose of this study is obtain the affect of discovery-inquiry learning } \\
\text { method on student's critical thinking skill achievement in topic of } \\
\text { solubility. Method of research is pre-experimental and one-shot case } \\
\text { study as the design of method research. Subjects were } 41 \text { students at } \\
\text { one of the senior high school in Bandung. Instruments of this research } \\
\text { are six questions of written test and interview guidelines. Highes } \\
\text { achievement at the whole sub indicators is the high ability student's } \\
\text { group. Overall, the student's critical thinking skill achievement on } \\
\text { factors affecting solubility's learning with discovery-inquiry is good. }\end{array}$} \\
\hline Revised & : 2020-04-07 & \\
\hline Accepted & : 2020-04-08 & \\
\hline \multicolumn{2}{|c|}{$\begin{array}{l}\text { Keyword: } \\
\text { Kata kunci: keterampilan } \\
\text { berpikir kritis, discovery- } \\
\text { inquiry, kelarutan }\end{array}$} & \\
\hline $\begin{array}{l}\text { Kata kunci: } \\
\text { berpikir krit } \\
\text { inquiry, kel }\end{array}$ & $\begin{array}{l}\text { terampilan } \\
\text { discovery- } \\
\text { tan }\end{array}$ & \\
\hline
\end{tabular}

\section{Pendahuluan}

Sistem pendidikan membutuhkan pembaharuan seiring dengan kemajuan jaman. Perkembangan revolusi industri secara tidak langsung merubah sistem pendidikan suatu negara. Revolusi industri 4.0 dikenal dengan era revolusi digital atau era disrupsi sebagai suatu inovasi fundamental di bidang ilmu pengetahuan dan teknologi (Kasali, 2018). Pada era revolusi industri 4.0, dunia pendidikan dituntut untuk dapat membekali siswa dengan empat keterampilan abad 21 terpenting atau dikenal dengan "Four Cs", yaitu: keterampilan berpikir kritis, komunikasi, kolaborasi, dan kreatif (NEA, 2012). Keterampilan berpikir kritis (KBKr) menjadi syarat utama dalam melaksanakan pendidikan agar dapat memenuhi perkembangan kemajuan jaman (Ahuna, Buffalo, Kiener, 2014). KBKr tergolong ke dalam kemampuan berpikir tingkat tinggi.

$\mathrm{KBKr}$ dapat dimiliki siswa dengan latihan berpikir kritis yang dikembangkan selama pembelajaran berlangsung dengan bimbingan pengajar/guru. Karakterisasi $\mathrm{KBKr}$ adalah keterampilan menganalisis, mensintesis, mengidentifikasi masalah, membuat alasan, melakukan evaluasi, menarik kesimpulan, dan menyelesaikan masalah (Suardana, Redhana, Sudiatmika, 2018: 400). Siswa yang mengalami keragu-raguan dan merasa ambigu terhadap materi yang sedang dipelajari merupakan

*Corresponding Author:

$\begin{array}{ll}\text { Nama } & \text { : Fina Khaerunnisa Frima } \\ \text { Lembaga } & \text { : Institut Teknologi Sumatera } \\ \text { Email } & \text { : fina.khaerunissa@ki.itera.ac.id }\end{array}$


pertanda bahwa siswa sedang menggunakan $\mathrm{KBKr}$ dalam proses pembelajaran (Balencia \& Ocampo, 2018: 110). Pada kenyataannya, siswa belum dibiasakan untuk dapat berpikir kritis di level menganalisis, mensintesis, dan mengevaluasi materi pelajaran yang diterima (Syahbana, 2012: 46).

Kerangka luaran pembelajaran abad 21 menekankan pada keterampilan belajar dan inovasi, keterampulan informasi, media, dan teknologi, keterampilan hidup dan karir (Sanabria \& Lizarraga, 2017: 490). Idealnya guru harus menyiapkan pembelajaran yang dapat menstimulasi siswa untuk belajar berpikir kritis dalam usaha memahami pengetahuan (hukum, fakta, konsep, dan prosedur kerja). Salah satu hal yang dibutuhkan dalam mengembangkan $\mathrm{KBKr}$ siswa adalah dengan memodifikasi metode pembelajaran yang dipakai, yaitu dengan menggunakan metode pembelajaran discovery-inquiry.

Pembelajaran dengan metode discovery merupakan salah satu strategi pembelajaran dengan menekankan pada keaktifan siswa dalam menemukan ilmu melalui konsep penemuan. Sedangkan metode inquiry adalah pengembangan metode discovery yang disertai dengan mengajukan pertanyaan, pencarian, dan penyelidikan secara sistematis, kritis, dan analitis. Prinsip pembelajaran yang menerapkan metode inquiry, yaitu: (1) Orientasi dalam pengembangan kemampuan berpikir dalam menemukan ilmu, (2) Interaksi siswa dengan guru, antar siswa, dan sumber belajar lainnya, (3) Belajar untuk bertanya, siswa diarahkan untuk dapat berpikir kritis mengenai topik yang sedang dipelajari dengan mengajukan pertanyaan yang terarah, (4) Keterbukaan, siswa diberikan kesempatan dalam mengajukan dan membuktikan hipotesis (Solichin, 2017: 219-220).

Metode discovery-inquiry merupakan cara penyajian pelajaran yang banyak melibatkan siswa dalam proses-proses mental dalam rangka penemuannya (Amien, 1987). Pelaksanaan pembelajaran dengan metode discovery-inquiry menekankan siswa untuk dapat menggunakan KBKr-nya, sehingga siswa berperan aktif selama kegiatan pembelajaran sebagai suatu aktivitas mental yang terwujud pada tahapan-tahapan pembelajaran discoveryinquiry dalam memperoleh pengetahuan. Tahapan-tahapan dalam metode pembelajaran discovery-inquiry yaitu: stimulasi, perumusan masalah, pengumpulan data, analisis data, verifikasi, dan generalisasi (Makmun, 2003).
$\mathrm{KBKr}$ sangatlah bermanfaat dan jika terbiasa menggunakannya selama kegiatan pembelajaran kimia, maka sesungguhnya $\mathrm{KBKr}$ itu dapat meningkatkan pemahaman dalam mempelajari kimia (Fisher, 2009). Berikut adalah beberapa penelitian tentang pencapaian $\mathrm{KBKr}$ pada materi kimia yaitu materi perkembangan konsep redoks (Nurmalinda, 2011) dan efek Tyndall (Rahayu, 2010), serta materi sifat-sifat koloid (Purlistyani, 2012), maka materi yang dipilih untuk dikembangkan dalam penelitian ini yaitu "Faktor-faktor yang Mempengaruhi Kelarutan", terdiri dari sub materi pengaruh jenis pelarut, suhu, pengadukan, ion senama dan $\mathrm{pH}$ terhadap kelarutan.

Pemilihan materi didasarkan pada materi faktor-faktor yang mempengaruhi kelarutan biasanya diajarkan dengan metode ceramah, sehingga tidak cocok dalam pembentukkan $\mathrm{KBKr}$ yang perlu dimiliki siswa. Selain itu, materi ini erat kaitannya dengan fenomena dalam kehidupan sehari-hari, sehingga dapat memudahkan siswa untuk menggunakan $\mathrm{KBKr}$ dalam menemukan sendiri pengetahuannya yang berasal dari fenomena melalui metode discovery-inquiry. Berdasarkan beberapa penelitian sebelumnya, penggunaan metode pembelajaran guided discovery lebih efektif diterapkan dalam mempelajari ilmu sains dan tingkat pencapaian adalah tinggi (Abdisa \& Getinet, 2012: 530).

Penelitian mengenai pencapaian $\mathrm{KBKr}$ siswa dalam pembelajaran yang menerapkan metode discovery-inquiry pada materi faktorfaktor yang mempengaruhi kelarutan, dengan tujuan untuk memperoleh gambaran tentang pencapaian keterampilan berpikir kritis siswa pada pembelajaran faktor-faktor yang mempengaruhi kelarutan dengan metode discovery-inquiry.

\section{Metode Penelitian}

\section{Jenis Penelitian}

Penelitian ini menggunakan pendekatan kualitatif deskriptif. Metode penelitian yang digunakan adalah metode preexperimental. Variabel terikat pada penelitian ini adalah pencapaian keterampilan berpikir kritis, sedangkan variabel bebasnya adalah metode discovery-inquiry. Penelitian dirancang dengan desain one-shot case study. 


\section{Waktu dan Tempat Penelitian}

Penelitian ini dilaksanakan di SMAN 11 Bandung pada kelas XI IPA pada semester genap pembelajaran berlangsung.

\section{Subjek Penelitian}

Subjek dalam penelitian ini adalah siswa kelas XI semester 2 pada tahun ajaran 2012/2013, sebanyak satu kelas dengan jumlah siswa sebanyak 41, yang kemudian dikelompokkan menjadi tiga kelompok siswa, yaitu tinggi, sedang, dan rendah. Pengelompokkan siswa dihitung berdasarkan nilai mean dan standar deviasi ulangan harian mata pelajaran kimia. Penentuan sampel sebagai subjek penelitian dilakukan dengan teknik non probability sampling yaitu sampling purposive.

\section{Prosedur}

Terdapat dua tahapan dalam desain, yaitu: tahap persiapan dan tahap pelaksanaan penelitian. Tahap persiapan meliputi: menganalisis standar isi kimia SMA, melakukan studi literatur mengenai materi faktor-faktor yang mempengaruhi kelarutan (dengan sub materi: pengaruh jenis pelarut, suhu, pengadukan, ion senama dan $\mathrm{pH}$ terhadap kelarutan), metode pembelajaran discoveryinquiry, KBKr. Selanjutnya menyusun rencana pelaksanaan pembelajaran (RPP), membuat dan menvalidasi instrumen penelitian. Tahap pelaksanaan penelitian meliputi: pelaksanaan kegiatan pembelajaran pada materi faktorfaktor yang mempengaruhi kelarutan dengan metode discovery-inquiry, dilanjutkan pelaksanaan tes tertulis keterampilan berpikir kritis pada seluruh siswa, dan pelaksanaan wawancara terhadap beberapa siswa yang dapat mewakili kelompok siswa tinggi, sedang dan rendah

\section{Instrumen}

Instrumen yang digunakan dalam penelitian ini berupa tes tertulis dan pedoman wawancara. Tes tertulis terdiri dari enam soal uraian, dimana tiap soalnya sesuai dengan sub indikator keterampilan berpikir kritis yang dikembangkan menurut Ennis dalam Costa (1985), yaitu: keterampilan mengungkapkan masalah, mengemukakan hipotesis, merancang eksperimen, membuat pertimbangan, memberikan alasan dan mengemukakan kesimpulan. Baik tes tertulis maupun wawancara digunakan pula untuk mengumpulkan data mengenai pencapaian keterampilan berpikir kritis siswa.

\section{Teknik Analisis Data}

Berikut adalah langkah-langkah yang dilakukan dalam menganalisis data hasil penelitian:

\section{Tes Tertulis}

a) Memberikan total skor mentah jawaban setiap siswa pada tes tertulis.

b) Mengubah skor mentah menjadi nilai persentase, dengan rumus:

Nilai persentase $=\frac{\text { Eskor mentah }}{\sum \text { skor maksimal }} \times 100 \%$

c) Menghitung nilai yang diperoleh siswa dalam masing-masing kategori siswa (tinggi, sedang dan rendah) untuk setiap sub indikator keterampilan berpikir kritis yang dikembangkan.

d) Menghitung nilai rata-rata yang diperoleh siswa pada masing-masing kategori siswa (tinggi, sedang dan rendah) untuk setiap sub indikator keterampilan berpikir kritis yang dikembangkan.

e) Menghitung nilai rata-rata yang diperoleh siswa dalam masing-masing kategori siswa (tinggi, sedang dan rendah) untuk seluruh sub indikator keterampilan berpikir kritis yang dikembangkan.

f) Menghitung nilai rata-rata yang diperoleh seluruh siswa untuk setiap sub indikator keterampilan berpikir kritis yang dikembangkan.

g) Menghitung nilai rata-rata seluruh siswa untuk seluruh sub indikator keterampilan berpikir kritis yang dikembangkan.

h) Menentukan kategori kemampuan seluruh siswa berdasarkan skala kriteria kemampuan sesuai dengan Arikunto (2009).

i) Mendeskripsikan data penelitian mengenai pencapaian masing-masing sub indikator keterampilan berpikir kritis siswa kelompok tinggi, sedang, dan rendah, pencapaian keseluruhan sub indikator keterampilan berpikir kritis siswa kelompok tinggi, sedang, dan rendah, serta pencapaian keseluruhan sub indikator keterampilan berpikir seluruh siswa.

\section{Wawancara}


Hasil wawancara dianalisis dan digabungkan dengan data jawaban tes, sebagai data pendukung yang dapat membahas pencapaian keterampilan berpikir kritis dalam materi faktor-faktor yang mempengaruhi kelarutan dengan metode discovery-inquiry.

\section{Hasil Penelitian dan Pembahasan}

\section{Hasil Penelitian}

Data penelitian yang diperoleh adalah pencapian setiap sub indikator $\mathrm{KBKr}$ yang dikembangkan (keterampilan mengungkapkan masalah, mengemukakan hipotesis, merancang eksperimen, membuat pertimbangan, memberikan alasan, dan mengemukakan kesimpulan) pada setiap kelompok siswa (tinggi, sedang, dan rendah).

\section{Data Pencapaian Keterampilan Mengungkapkan Masalah}

Pada sub indikator keterampilan mengungkapkan masalah, siswa dibimbing untuk dapat menuliskan masalah ke dalam bentuk pertanyaan sesuai dengan artikel. Artikel memuat masalah tentang fakta-fakta dalam kehidupan sehari-hari yang berhubungan dengan materi faktor-faktor yang mempengaruhi kelarutan. Berdasarkan jawaban siswa pada tes tertulis, diketahui pencapaian keterampilan mengungkapkan masalah dapat dilihat pada Gambar 1.

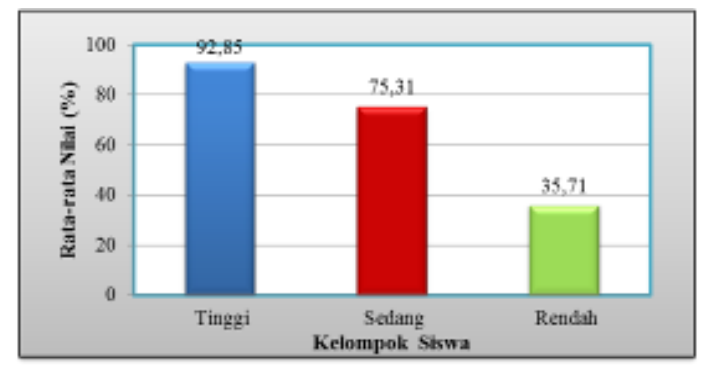

Gambar 1. Pencapaian Keterampilan Mengungkapkan Masalah

\section{Data Pencapaian Keterampilan Mengemukakan Hipotesis}

Keterampilan mengemukakan hipotesis diuji untuk mengetahui bagaimana pencapaian siswa dalam menuliskan jawaban sementara dari permasalahan yang telah diajukan sebelumnya berdasarkan artikel mengenai materi faktor-faktor yang mempengaruhi kelarutan. Hasil menunjukkan terdapat selisih pencapaian keterampilan mengemukakan hipotesis antara kelompok siswa pada Gambar 2.

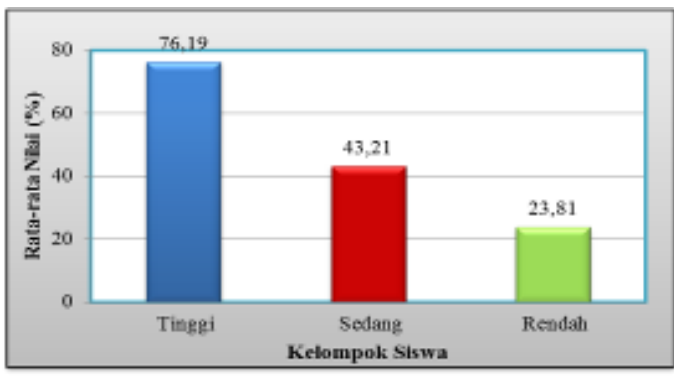

Gambar 2. Pencapaian Keterampilan Mengemukakan Hipotesis

\section{Data Pencapaian Keterampilan Merancang Eksperimen}

Pengajuan hipotesis yang telah dinyatakan sebagai jawaban sementara terhadap permasalahan yang diajukan, masih perlu diuji kebenarannya. Siswa dalam menguji kebenaran hipotesis yang telah diajukan, maka diberi kesempatan untuk merancang eksperimen. Hasil dari jawaban tes menunjukkan bahwa pencapaian keterampilan merancang eksperimen dapat dilihat pada Gambar 3.

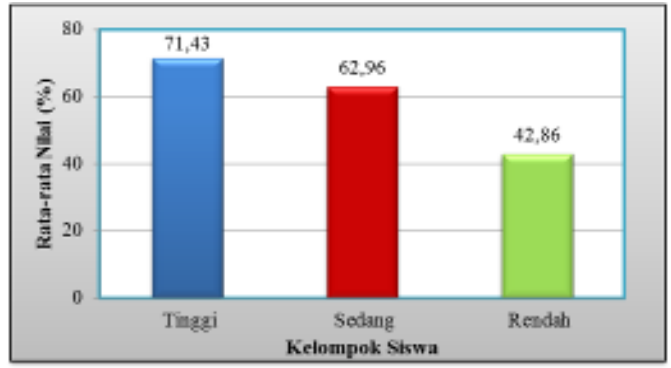

Gambar 3. Pencapaian Keterampilan Merancang Eksperimen

\section{Data Pencapaian Keterampilan Membuat Pertimbangan}

Pertimbangan berdasarkan data eksperimen dibuat untuk menuntun siswa dalam proses mengkonseptualisasikan fakta dari hasil eksperimen yang didapat menjadi suatu konsep yang benar mengenai materi yang sedang dipelajari. Hasil tes menunjukkan bahwa pencapaian keterampilan membuat pertimbangan pada siswa dapat dilihat pada Gambar 4. 


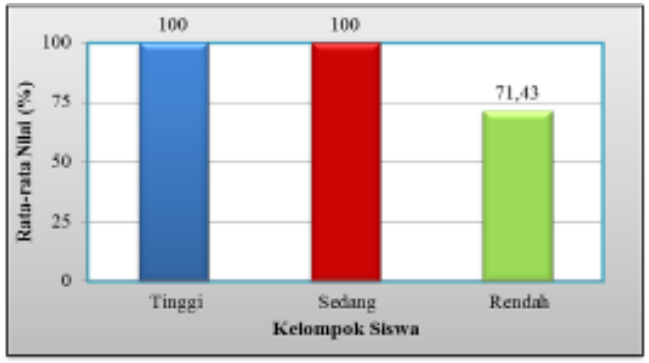

Gambar 4.

Pencapaian Keterampilan Membuat Pertimbangan

\section{Data Pencapaian Keterampilan Memberikan Alasan}

Keterampilan memberikan alasan diuji untuk mengetahui penjelasan siswa terhadap materi berdasarkan hasil eksperimen. Berdasarkan jawaban siswa pada tes tertulis, diketahui pencapaian keterampilan memberikan alasan dapat dilihat pada Gambar 5.

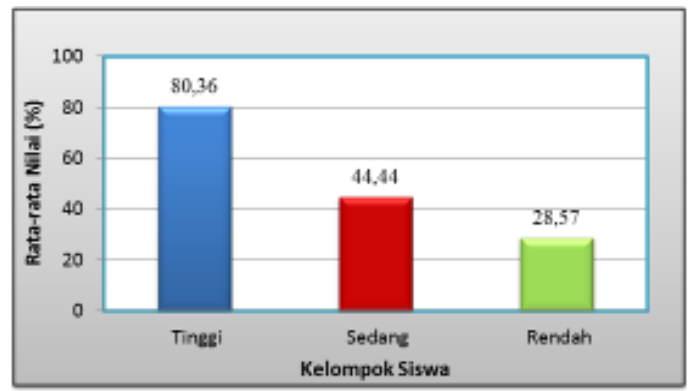

Gambar 5. Pencapaian Keterampilan Memberikan Alasan

\section{Data Pencapaian Keterampilan Mengemukakan Kesimpulan}

Berdasarkan jawaban siswa pada tes tertulis, diketahui pencapaian keterampilan mengemukakan kesimpulan pada siswa kelompok tinggi, sedang dan rendah yaitu kriteria sangat baik dapat dilihat pada Gambar 6.

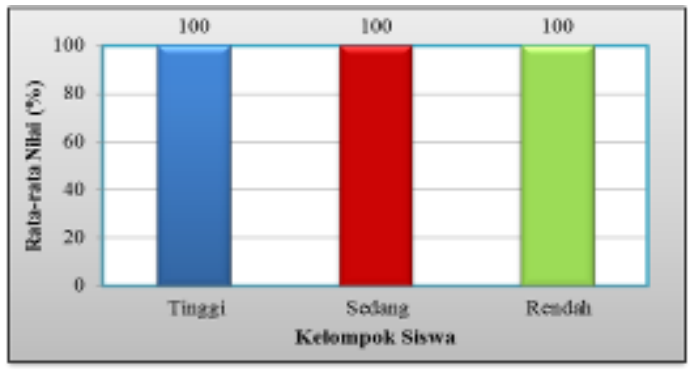

Gambar 6.

Pencapaian Keterampilan Mengemukakan Kesimpulan
7. Data Pencapaian Keseluruhan Sub Indikator KBKr pada Kelompok Siswa

Gambar 7. menunjukkan hasil pencapaian keseluruhan sub indikator $\mathrm{KBKr}$ (keterampilan mengungkapkan masalah, mengemukakan hipotesis, merancang eksperimen, membuat pertimbangan, memberikan alasan dan mengemukakan kesimpulan) pada setiap kelompok siswa (tinggi, sedang, dan rendah).

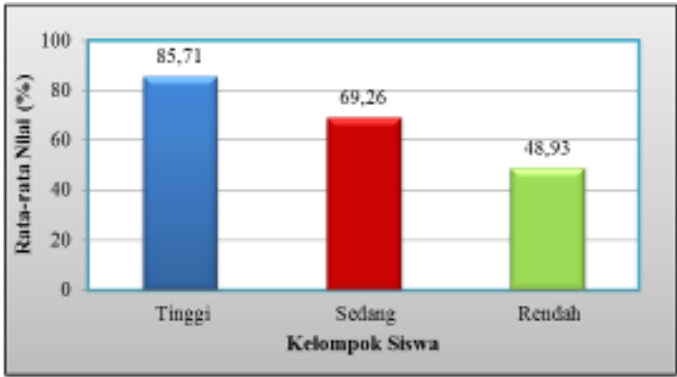

Gambar 7. Pencapaian Keseluruhan Sub Indikator $\mathrm{KBKr}$ pada Kelompok Siswa

\section{Pembahasan}

\section{Pencapaian Keterampilan Mengungkapkan Masalah}

Hasil penelitian menunjukkan pencapaian keterampilan mengungkapkan masalah pada siswa kelompok rendah, sedang, dan tinggi adalah masing-masing yaitu kurang, baik, dan sangat baik. Adanya selisih pencapaian keterampilan mengungkapkan masalah yang cukup besar antara siswa kelompok tinggi dan sedang dengan siswa kelompok rendah. Hal ini menandakan bahwa siswa kelompok rendah mengalami kesulitan dalam mengungkapkan masalah. Siswa kelompok tinggi cenderung melakukan persiapan sebelum mengikuti pembelajaran, seperti membaca materi terlebih dahulu, berbeda halnya dengan siswa kelompok rendah yang tidak membaca materi sebelum pembelajaran dimulai. Hasil yang ditunjukkan oleh ketiga kelompok siswa ini tidak ada yang mencapai rata-rata nilai 100 , dikarenakan siswa baru pertama kali mengungkapkan suatu masalah dalam pembelajaran kimia yang menyebabkan siswa masih belum terbiasa untuk mengungkapkan suatu masalah. Diketahui bahwa proses pembelajaran yang telah dilakukan sebelumnya adalah dalam 
bentuk ceramah, yang hanya sebatas pada proses transfer of knowledge tanpa adanya proses melatih $\mathrm{KBKr}$ siswa terutama keterampilan mengungkapkan masalah. Hal tersebut sejalan dengan yang diungkapkan Daryanto (2012), bahwa pembelajaran dengan metode ceramah cenderung bersifat verbalistik dari guru dan bertumpu hanya pada kepentingan pengajar dibanding dengan kebutuhan siswa. Menurut Danial (2018) bahwa pembelajaran dengan metode ceramah menjadi pembelajaran yang kurang efektif dan tidak dapat melatih $\mathrm{KBKr}$ siswa, terutama dalam keterampilan mengungkapkan masalah, disebabkan karena siswa tidak terbiasa mengungkapkan masalah dan merasa ragu untuk bertanya. Pembelajaran dengan metode ceramah tidak sejalan dengan proses pembelajaran dengan menuntut adanya interaksi komunikasi aktif antara siswa dengan guru, yaitu terdapat kegiatan belajar siswa dan kegiatan mengajar guru yang berlangsung bersamaan dalam kurun waktu yang sama menurut Arifin (2003), sehingga KBKr dapat dikembangkan dengan baik.

\section{Pencapaian Keterampilan Mengemukakan Hipotesis}

Hasil penelitian menunjukkan bahwa pencapaian keterampilan mengemukakan hipotesis pada masing-masing siswa kelompok tinggi, sedang, dan rendah adalah baik, cukup dan kurang. Soal pada tes yang diajukan untuk menguji pencapaian keterampilan mengemukakan hipotesis, mengandung hal mendasar yang perlu diperhatikan siswa untuk dapat mengemukakan hipotesis secara tepat.

Berdasarkan tes, siswa harus hapal sifat kepolaran senyawa yang telah dipelajari oleh siswa pada pembelajaran sebelumnya. Siswa yang mengetahui sifat kepolaran senyawa menunjukkan bahwa siswa mempunyai informasi untuk digunakan dalam menjawab permasalahan, maka akan semakin mudah siswa dalam mengemukakan hipotesis secara tepat. Hal ini sesuai dengan yang dinyatakan oleh Nazir (2005), bahwa dalam menggali hipotesis siswa harus mempunyai banyak informasi mengenai masalah yang ingin dipecahkan.

Berdasarkan hasil wawancara, siswa kelompok sedang lupa bagaimana sifat kepolaran senyawa. Siswa yang lupa terhadap materi kepolaran senyawa artinya tidak mempunyai informasi untuk dapat digunakan dalam menjawab permasalahan, sehingga tidak mendapatkan hasil yang maksimal dalam mengemukakan hipotesis.

Siswa kelompok rendah memperoleh pencapaian yang paling rendah dibanding kelompok tinggi dan sedang, menandakan bahwa siswa kelompok rendah mengalami kesulitan dalam mengemukakan hipotesis pada tes tertulis. Hal tersebut dapat dijelaskan bahwa selama pembelajaran, siswa kelompok rendah berlaku cenderung pasif ketika diskusi dilaksanakan dalam menjawab permasalahan yang ada, padahal Daryanto (2012) menyatakan bahwa berlaku pasif dalam diskusi adalah tidak benar. Perilaku pasif siswa dapat terlihat ketika siswa hanya mencatat ulang apa yang telah dicatat oleh teman sekelompoknya selama pembelajaran, tanpa mengetahui bagaimana penjelasannya.

Fenomena yang terjadi pada siswa kelompok rendah tersebut dikarenakan mereka memerlukan waktu yang lebih lama untuk mencari dan mengolah informasi, ditegaskan oleh Randall dalam Warsono (2012) bahwa siswa yang lebih cerdas seringkali meninggalkan siswa yang lebih lemah dalam pembelajaran. Hal ini bertolak belakang dari yang seharusnya ditunjukkan oleh siswa yang memiliki keterampilan berpikir kritis, bahwa siswa cenderung tidak menerima begitu saja gagasan-gagasan dan informasi-informasi dari orang lain, dan siswa seharusnya aktif sendiri dalam mencari informasi.

\section{Pencapaian Keterampilan Merancang Eksperimen}

Hasil penelitian menunjukkan bahwa pencapaian keterampilan merancang eksperimen pada siswa kelompok tinggi dan sedang adalah baik, sedangkan pencapaian keterampilan merancang eksperimen pada siswa kelompok rendah adalah cukup. Minimnya pengetahuan siswa menjadikan sebagai salah satu alasan yang dapat menyebabkan siswa mengalami kesulitan dalam merancang eksperimen, yaitu hampir semua siswa bertanya pada guru mengenai nama alat, dan bahan, serta fungsinya yang dapat dipakai dalam melakukan eksperimen. Sering bertanyanya siswa pada guru menunjukkan bahwa siswa pada dasarnya tidak mengetahui alat dan bahan-bahan kimia, serta tidak tahu apa fungsi dari masing-masing alat dan bahan yang akan digunakan. Hal ini sejalan dengan hasil penelitian yang dilakukan oleh Wulandari 
(2011), yang menyatakan bahwa sebenarnya kesulitan siswa dalam merancang eksperimen berpangkal pada ketidaktahuan mereka terhadap apa yang akan mereka kerjakan, serta kurangnya pengetahuan siswa akan alat dan bahan praktikum yang ada di laboratorium.

\section{Pencapaian Keterampilan Membuat Pertimbangan}

Hasil penelitian menunjukkan bahwa pencapaian keterampilan membuat pertimbangan pada siswa kelompok tinggi dan sedang adalah sangat baik, sedangkan pada siswa kelompok rendah adalah baik Berdasarkan hasil wawancara, siswa kelompok tinggi dan sedang tidak mengalami kesulitan dalam membuat pertimbangan dikarenakan hasil eksperimen sudah jelas mengarahkan pada konsep yang benar mengenai materi faktorfaktor yang mempengaruhi kelarutan. Pada kegiatan menganalisis data hasil eksperimen yang didapatkan selama pembelajaran, siswa menggunakan buku sumber belajar kimia yang ternyata konsep di buku sesuai dengan hasil eksperimen. Hal tersebut sesuai dengan yang diungkapkan oleh Sudirman dalam Dharmawan (2008) bahwa dengan metode discoveryinquiry, siswa belajar dengan memanfaatkan berbagai jenis sumber belajar yang tidak hanya menjadikan guru sebagai satu-satunya sumber belajar. Ketika siswa membuat pertimbangan berarti mereka melakukan pembuktian apakah hasil eksperimen yang didapatkan sesuai dengan konsep dalam buku. Hal yang dilakukan siswa sesuai dengan pendapat Glaser dalam Fisher (2009) yaitu dalam berpikir kritis menuntut upaya untuk memeriksa setiap keyakinan atau pengetahuan asumtif yang berasal dari hasil eksperimen berdasarkan bukti pendukungnya yang didapat dari sumber belajar kimia.

\section{Pencapaian Keterampilan Memberikan Alasan}

Siswa kelompok tinggi tidak mengalami kesulitan dalam memberikan alasan. Hasil wawancara mengungkapkan bahwa siswa telah memahami materi mengenai faktor-faktor yang mempengaruhi kelarutan. Pemahaman siswa kelompok tinggi terhadap materi didasarkan pada kemampuan siswa dalam mengumpulkan informasi yang sesuai, kemudian mengolah informasi tersebut menjadi suatu alasan yang dapat menjawab soal mengenai keterampilan memberikan alasan dengan tepat. Kedua hal tersebut telah dilakukan oleh siswa kelompok tinggi selama pembelajaran, sehingga mereka dapat menggunakan daya pikirnya dalam memberikan alasan terhadap suatu permasalahan. Hal ini sejalan dengan hasil penelitan sebelumnya oleh Pangesti (2011) yang menyatakan bahwa siswa kelompok tinggi telah dapat mengembangkan daya pikir atau penalaran maupun pemahaman yang mereka miliki untuk digunakan dalam memberikan alasan pada suatu permasalahan.

Pencapaian yang diperoleh oleh siswa kelompok tinggi menggambarkan bahwa mereka tidak memberikan alasan secara asal, melainkan secara logis. Siswa kelompok tinggi cenderung melakukan studi pustaka untuk lebih menegaskan konsep yang sudah didapat. Hal ini sesuai dengan pendapat Arifin (2003) yang menunjukkan bahwa apabila siswa memiliki keterampilan berpikir kritis, maka ia dapat memberikan alasan-alasan yang logis.

Selisih yang besar antara kelompok tinggi dengan dua kelompok lainnya yaitu sedang dan rendah, dikarenakan siswa kelompok sedang dan rendah kurang dapat mengembangkan daya pikirnya untuk dapat memberikan alasan yang tepat terhadap suatu permasalahan. Hasil wawancara menunjukkan bahwa siswa masih merasa kebingungan terhadap materi yang dipelajari, khususnya dalam menentukan arah pergeseran kesetimbangan berdasarkan pengaruh suhu. Kebingungan yang dialami oleh siswa kelompok sedang dan rendah disebabkan tidak melakukannya studi pustaka dalam upaya untuk lebih memahami konsep yang telah didapat. Hal ini tidak sejalan dengan yang diungkapkan oleh Sudirman dalam Dharmawan (2008) bahwa dengan metode discovery-inquiry menekankan siswa kepada proses pengolahan informasi, di mana siswa yang aktif mencari dan mengolah sendiri untuk dapat memahami materi yang sedang dipelajari.

\section{Pencapaian Keterampilan Mengemukakan Kesimpulan}

Hasil wawancara pada siswa kelompok tinggi menunjukkan bahwa siswa kelompok tinggi memang sudah memahami materi faktorfaktor yang mempengaruhi kelarutan, sehingga mempermudah mereka dalam mengemukakan kesimpulan. Hal ini sejalan dengan yang dijelaskan pada penelitian sebelumnya oleh Wulandari (2011), yaitu mudahnya siswa yang telah memahami materi dalam mengemukakan 
kesimpulan, menunjukkan bahwa siswa telah memiliki tingkat berpikir yang tinggi karena dalam penarikan kesimpulan membutuhkan proses pengaitan dari beberapa informasi yang telah didapat. Siswa kelompok tinggi dapat mengemukakan kesimpulan dengan sangat baik menunjukkan bahwa dengan metode pembelajaran discovery-inquiry membuat siswa mampu mengumpulkan informasi, kemudian memahami informasi tersebut sampai akhirnya diperoleh suatu kesimpulan yang sesuai.

Lain halnya dengan siswa kelompok sedang dan rendah, hasil wawancara menunjukkan bahwa siswa cenderung hanya mengingat bagian kesimpulan, tanpa membutuhkan proses pengaitan dari beberapa informasi yang telah didapat. Siswa berpikir bahwa kesimpulan merupakan hal terpenting dalam suatu pembelajaran, karena kesimpulan dianggap melakukan verifikasi data. Siswa yang cenderung hanya mengingat bagian kesimpulan, mengakibatkan tidak dapat diukur sejauh mana siswa telah memahami materi mengenai faktor-faktor yang dapat mempengaruhi kelarutan.

\section{Pencapaian Keseluruhan Sub Indikator KBKr pada Kelompok Siswa}

Hasil penelitian menegaskan bahwa siswa kelompok tinggi atau siswa dengan kemampuan kognitif tertinggi ternyata dapat mengembangkan KBKrnya secara lebih baik dibanding kelompok siswa lainnya selama pembelajaran. Kelompok tinggi menggunakan dan mengembangkan KBKrnya sebagai suatu cara dalam memperoleh kemampuan kognitifnya yaitu untuk lebih dapat memahami materi. Hal tersebut sesuai dengan yang diungkapkan oleh Costa (1985) bahwa KBKr dapat diajarkan sebagai suatu prasyarat bagi kemampuan kognitif.

\section{Simpulan dan Saran}

\section{Simpulan}

Pencapaian keseluruhan sub indikator keterampilan berpikir kritis seluruh siswa pada pembelajaran faktor-faktor yang mempengaruhi kelarutan dengan menggunakan metode discovery-inquiry yaitu tergolong baik $(68,60 \%)$.

\section{Saran}

Perlunya pembiasaan siswa untuk membaca terlebih dahulu materi sebelum pembelajaran dimulai dan aktif menggunakan berbagai sumber pelajaran ketika pembelajaran berlangsung agar siswa lebih mudah dalam menemukan konsepnya secara mandiri.

\section{Ucapan Terima Kasih}

Terimakasih disampaikan pada almamater Program Studi Pendidikan Kimia Fakultas Pendidikan Matematika dan Ilmu Pengetahuan Alam Universitas Pendidikan Indonesia.

\section{Daftar Pustaka}

Rhenald Kasali. (2018). Self Disruption. Jakarta: Mizan.

NEA. (2012). Preparing 21st Century Students for a Global Society: An Educator's Giude to the "Four Cs". Diakses tanggal 10 Oktober 2018 dari www.nea.org/assets/docs/A-Guide-toFour-Cs.pdf.

Ahuna, K.H., Buffalo, C.G.T \& Kiener, M. (2014). A New Era of Critical Thinking in Professional Programs. Transformartive Dialogues: Teaching \& Learning Journal, 7 (3), 1-9.

Suardana, I.N., Redhana, I.W., Sudiatmika, A.A.I.A.R. (2018). Student's Critical Thinking Skills in Chemistry Learning Using Local Culture-Bbased 7E Learning Cycle Model. International Journal of Instruction, 11 (2), 399-412.

Balencia, R.R. \& Ocampo, J.M. (2018). Effecting Change on Student's Critical Thinking in Problem Solving. Educare: International Journal for Educational Studies, 10 (2), 109-118.

Syahbana, A. (2012). Peningkatan Kemampuan Berpikir Kritis Matematis Siswa SMP Melalui Pendekatan Contextual Teaching and Learning. Edumatica, 2 (1), 45-57.

Sanabria, J.C. \& Lizarraga, J.A. (2017). Enhancing $21^{\text {st }}$ Century Skills with AR: Using the Gradual Immersion Method to Develop Collaborative Creativity. EURASIA Journal of Mathematics Science and Technology Education, 13 (2), 487-501.

Solichin, M.M. (2017). Penerapan Model Pembelajaran Inquiry Discovery dalam 
Pendidikan Agama Islam. Tadris, 12 (2), 214-231.

Amien, M. (1987). Mengajarkan Ilmu Pengetahuan Alam (IPA) dengan Menggunakan Metode Discovery dan Inquiry. Jakarta: Depdikbud.

Makmun, A.S. (2003). Psikologi Pendidikan. Bandung: PT. Remaja Rosdakarya.

Fisher, A. (2009). Berpikir Kritis: Sebuah Pengantar. Jakarta: Erlangga.

Rahayu, D. (2010). Analisis Keterampilan Berpikir Kritis Siswa Kelas XI pada Pembelajaran Efek Tyndall dengan Metode Discovery-Inquiry. Skripsi, tidak dipublikasikan. Universitas Pendidikan Indonesia.

Nurmalinda. (2011). Analisis Keterampilan Berpikir Kritis Siswa Kelas X pada Pembelajaran Perkembangan Konsep Redoks dengan Metode DiscoveryInquiry. Skripsi, tidak dipublikasikan. Universitas Pendidikan Indonesia.

Purlistyani, I. (2012). Analisis Keterampilan Berpikir Kritis Siswa Kelas XI pada Pembelajaran Sifat-Sifat Koloid dengan Metode Discovery-Inquiry. Skripsi, tidak dipublikasikan. Universitas Pendidikan Indonesia.

Costa, A.L. (1985). Developing Minds: A Resource Book for Teaching Thinking. Virginia: Association for Supervision an Curriculum Development.

Arikunto, S. (2009). Evaluasi Program Pendidikan. Jakarta: Bumi Aksara.

Daryanto. \& Muljo, R. (2012). Model Pembelajaran Inovatif. Yogyakarta: Gaya Media Pratama.

Danial, M., Sawal, M., Nurlaela. (2018). Development of Chemistry Instructional Tools and Its Effect on Critical Thinking Skills, Metacognition, and Concept Mastery of Students. Journal of Physics: Conf. Series 1028, 1-8.
Arifin, M. (2003). Strategi Belajar Mengajar Kimia Bandung: Jurusan Pendidikan Kimia FPMIPA UPI.

Nazir. (2005). Metode Penelitian. Bogor: Ghalia Indonesia.

Warsono. \& Hariyanto. (2012). Pembelajaran Aktif: Teori dan Asesmen. Bandung: PT. Remaja Rosdakarya.

Wulandari, A.D. (2011). Pembelajaran Praktikum Berbasis Inkuiri Terbimbing untuk Meningkatkan Kemampuan Berpikir Kritis Siswa SMA pada Materi Laju Reaksi. Skripsi, tidak dipublikasikan. Universitas Pendidikan Indonesia.

Dharmawan, D. (2008). Discovery-Inquiry Sebuah Metode. Diakses tanggal 18 Desember 2012 dari http://dadhar.blogspor.com/2008/02/dis covery-inquiry-sebuah-metode.html.

Pangesti, E.R. (2011). Analisis Keterampilan Berpikir Kritis Siswa pada Kelas X pada Pembelajaran Larutan Elektrolit dan Non-Elektrolit dengan Siklus Belajar Hipotesis-Deduktif. Skripsi, tidak dipublikasikan. Universitas Pendidikan Indonesia. 